\title{
Preparation of p-type ZnMgO thin films by Sb doping method
}

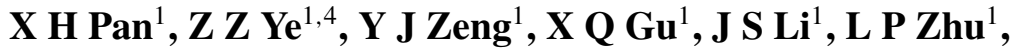 \\ B H Zhao ${ }^{1}, Y$ Che $^{2}$ and X Q Pan ${ }^{3}$ \\ ${ }^{1}$ State Key Laboratory of Silicon Materials, Zhejiang University, Hangzhou 310027, \\ People's Republic of China \\ 2 IMRA America, Inc., 1044 Woodridge Ave. Ann Arbor, MI 48105, USA \\ ${ }^{3}$ Department of Materials Science and Engineering, University of Michigan, Ann Arbor, \\ MI 48109-2136, USA
}

E-mail: yezz@zju.edu.cn

Received 27 March 2007, in final form 17 May 2007

Published 29 June 2007

Online at stacks.iop.org/JPhysD/40/4241

\begin{abstract}
We report on $\mathrm{Sb}$-doped p-type $\mathrm{Zn}_{0.95} \mathrm{Mg}_{0.05} \mathrm{O}$ thin films grown by pulsed laser deposition. The Sb-doped $\mathrm{Zn}_{0.95} \mathrm{Mg}_{0.05} \mathrm{O}$ films show an acceptable p-type conductivity with a resistivity of $126 \Omega \mathrm{cm}$, a Hall mobility of $1.71 \mathrm{~cm}^{2} \mathrm{~V}^{-1} \mathrm{~s}^{-1}$ and a hole concentration of $2.90 \times 10^{16} \mathrm{~cm}^{-3}$ at room temperature. Secondary ion mass spectroscopy confirms that $\mathrm{Sb}$ has been incorporated into the $\mathrm{Zn}_{0.95} \mathrm{Mg}_{0.05} \mathrm{O}$ films. Guided by x-ray photoemission spectroscopy analysis and a model for large-size-mismatched group- $\mathrm{V}$ dopants in $\mathrm{ZnO}$, an $\mathrm{Sb}_{\mathrm{Zn}}-2 \mathrm{~V}_{\mathrm{Zn}}$ complex is believed to be the most possible acceptor in the $\mathrm{Sb}$-doped p-type $\mathrm{Zn}_{0.95} \mathrm{Mg}_{0.05} \mathrm{O}$ thin films.
\end{abstract}

(Some figures in this article are in colour only in the electronic version)

\section{Introduction}

$\mathrm{ZnO}$, with a direct bandgap of $3.37 \mathrm{eV}$ and a large exciton binding energy of $60 \mathrm{meV}$ at room temperature, is presently receiving worldwide attention because of its advantages for short-wavelength optoelectronic devices $[1,2]$. It is well known that the bandgap of $\mathrm{ZnO}$ can be widened by doping with $\mathrm{MgO}$. Also, the ionic radius of $\mathrm{Mg}^{2+}(0.57 \AA)$ is close to that of $\mathrm{Zn}^{2+}(0.60 \AA)$. Therefore, $\mathrm{ZnMgO}$ is a suitable material for quantum confinement structures from the viewpoint of bandgap engineering [3]. However, realization of p-type $\mathrm{ZnO}$ and p-type $\mathrm{ZnMgO}$ is difficult due to the asymmetric doping limitations [4]. Thanks to considerable worldwide efforts, the recent breakthrough in p-type doping has made the applications of $\mathrm{ZnO}$ material more feasible [5-8]. In this regard, similar efforts to dope $\mathrm{ZnMgO}$ thin films are strongly demanded. On the other hand, the investigations on p-type $\mathrm{ZnMgO}$ films are currently limited. P-doped p-type $\mathrm{ZnMgO}$ fabricated by pulsed laser deposition (PLD) [9] and Al-N co-doped p-type ZnMgO fabricated by ultrasonic spray pyrolysis (USP) [10] have been reported. Recently, the synthesis of p-type $\mathrm{Zn}_{1-x} \mathrm{Mg}_{x} \mathrm{O}$ films by means of $\mathrm{Sb}$ doping has also been demonstrated

\footnotetext{
4 Author to whom any correspondence should be addressed.
}

[11]. However, the p-type doping mechanism is not well understood, especially for Sb doping. For device fabrication, a better understanding of doping behaviour in p-type $\mathrm{ZnMgO}$ is required. In this work, we investigate p-type behaviour in Sbdoped $\mathrm{Zn}_{0.95} \mathrm{Mg}_{0.05} \mathrm{O}$ thin films grown by PLD. The tailored properties of the films are readily presented.

\section{Experimental details}

Sb-doped $\mathrm{Zn}_{0.95} \mathrm{Mg}_{0.05} \mathrm{O}$ films were prepared on glass substrates by the PLD method. The substrates were cleaned with alcohol for $30 \mathrm{~min}$ and then rinsed in de-ionized water before being loaded into the chamber. The target was highpurity $\mathrm{ZnO}-\mathrm{MgO}-\mathrm{Sb}_{2} \mathrm{O}_{3}$ ceramic disc with a $\mathrm{Mg}$ content of 5 at\% and a $\mathrm{Sb}$ content of 2.96 at\%. A $\mathrm{KrF}$ excimer laser (Compex102, $248 \mathrm{~nm}, 25 \mathrm{~ns}$ ) was employed as the ablation source. The laser repetition rate was $3 \mathrm{~Hz}$ and the energy per pulse was $300 \mathrm{~mJ}$. The distance between the target and the substrate was $4.5 \mathrm{~cm}$. The vacuum chamber was evacuated to a base pressure of $4 \times 10^{-4} \mathrm{~Pa}$ and then high-purity $\mathrm{O}_{2}(99.999 \%)$ was introduced. The growth pressure was $0.7 \mathrm{~Pa}$. All the films were deposited at $400{ }^{\circ} \mathrm{C}$ for $45 \mathrm{~min}$.

The electrical properties of the films were examined by Hall-effect measurements using the van der Pauw 


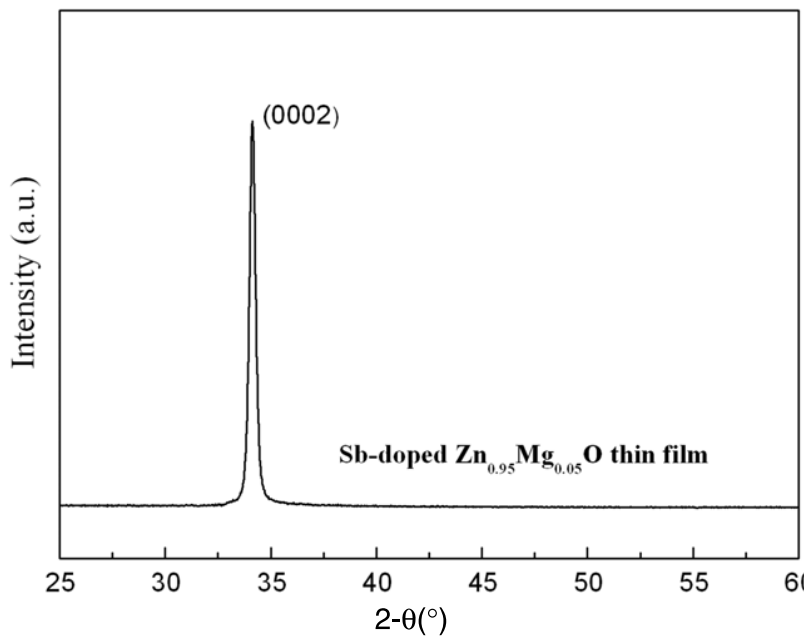

Figure 1. XRD pattern of Sb-doped $\mathrm{Zn}_{0.95} \mathrm{Mg}_{0.05} \mathrm{O}$ thin film deposited on glass substrate at $400{ }^{\circ} \mathrm{C}$.

configuration (BIO-RAD HL5500PC) at room temperature. $\mathrm{X}$-ray diffraction (XRD) analysis was performed on a Bede D1 system with $\mathrm{Cu} K \alpha$ radiation $(\lambda=0.15406 \mathrm{~nm})$. The depth profile of Sb-doped $\mathrm{Zn}_{0.95} \mathrm{Mg}_{0.05} \mathrm{O}$ thin film was measured by secondary ion mass spectroscopy (SIMS) (Cameca IMS-3f). Photoluminescence (PL) measurements were performed at room temperature on a Fluorolog-3-Tau fluorescence spectrometer. The chemical bonding states of $\mathrm{Mg}$ and $\mathrm{Sb}$ were analysed by $\mathrm{x}$-ray photoelectron spectroscopy (XPS) (Thermo ESCALAB 250, Al $K \alpha$ radiation source $h v=1486.6 \mathrm{eV})$.

\section{Results and discussion}

The average thickness of the films is approximately $300 \mathrm{~nm}$ measured by cross-sectional scanning electron microscopy (FEI Sirion 200 FEG SEM). Figure 1 shows the XRD pattern of the Sb-doped $\mathrm{Zn}_{0.95} \mathrm{Mg}_{0.05} \mathrm{O}$ thin film. Only a peak corresponding to the $\mathrm{ZnO}(0002)$ plane is observed, and no diffraction from other phases such as $\mathrm{Sb}_{2} \mathrm{O}_{3}$ or $\mathrm{MgO}$ is detected. It is suggested that the film is of acceptable crystallinity with a high preferential $c$-axis orientation.

For comparison, a $\mathrm{Sb}$-doped $\mathrm{ZnO}$ thin film was also prepared. The deposition process was exactly the same as that of the Sb-doped $\mathrm{Zn}_{0.95} \mathrm{Mg}_{0.05} \mathrm{O}$ thin film except that a highpurity $\mathrm{ZnO}-\mathrm{Sb}_{2} \mathrm{O}_{3}$ ceramic disc with $\mathrm{Sb}$ content of 2.96 at\% was used for the $\mathrm{Sb}$-doped $\mathrm{ZnO}$ thin film. Table 1 summarizes the electrical properties of the Sb-doped $\mathrm{ZnO}$ and $\mathrm{Sb}$-doped $\mathrm{Zn}_{0.95} \mathrm{Mg}_{0.05} \mathrm{O}$ thin films at room temperature. To examine the reliability of the results, Hall-effect measurements were repeated four times and similar results were obtained. The Sb-doped $\mathrm{ZnO}$ thin film exhibits p-type conductivity, but obviously worse than that of the Sb-doped $\mathrm{Zn}_{0.95} \mathrm{Mg}_{0.05} \mathrm{O}$ thin film. For the $\mathrm{Sb}$-doped $\mathrm{Zn}_{0.95} \mathrm{Mg}_{0.05} \mathrm{O}$ thin film, a resistivity of $126 \Omega \mathrm{cm}$, a Hall mobility of $1.71 \mathrm{~cm}^{2} \mathrm{~V}^{-1} \mathrm{~s}^{-1}$ and a hole concentration of $2.90 \times 10^{16} \mathrm{~cm}^{-3}$ were acquired. The results may be understood as follows. Observation of p-type conductivity in Sb-doped $\mathrm{ZnO}$ films indicates the formation of an acceptor state by Sb doping. At the same time, the addition of $\mathrm{Mg}$ can move the conduction band edge up in
Table 1. Electrical properties of Sb-doped $\mathrm{ZnO}$ and $\mathrm{Sb}$-doped $\mathrm{Zn}_{0.95} \mathrm{Mg}_{0.05} \mathrm{O}$ thin films deposited on glass substrates at $400{ }^{\circ} \mathrm{C}$.

\begin{tabular}{lllll}
\hline Sample & $\begin{array}{l}\text { Resistivity } \\
(\Omega \mathrm{cm})\end{array}$ & $\begin{array}{l}\text { Hall mobility } \\
\left(\mathrm{cm}^{2} \mathrm{~V}^{-1} \mathrm{~s}^{-1}\right)\end{array}$ & $\begin{array}{l}\text { Carrier } \\
\text { concentration } \\
\left(\mathrm{cm}^{-3}\right)\end{array}$ & $\begin{array}{l}\text { Carrier } \\
\text { type }\end{array}$ \\
\hline $\mathrm{ZnO}$ & 620 & 0.437 & $2.30 \times 10^{16}$ & $\mathrm{p}$ \\
$\mathrm{Zn}_{0.95} \mathrm{Mg}_{0.05} \mathrm{O}$ & 126 & 1.71 & $2.90 \times 10^{16}$ & $\mathrm{p}$ \\
$\mathrm{ZnMgO}$ & 151 & 2.25 & $1.83 \times 10^{16}$ & $\mathrm{p}$ \\
(30 days later) & & & & \\
\hline
\end{tabular}

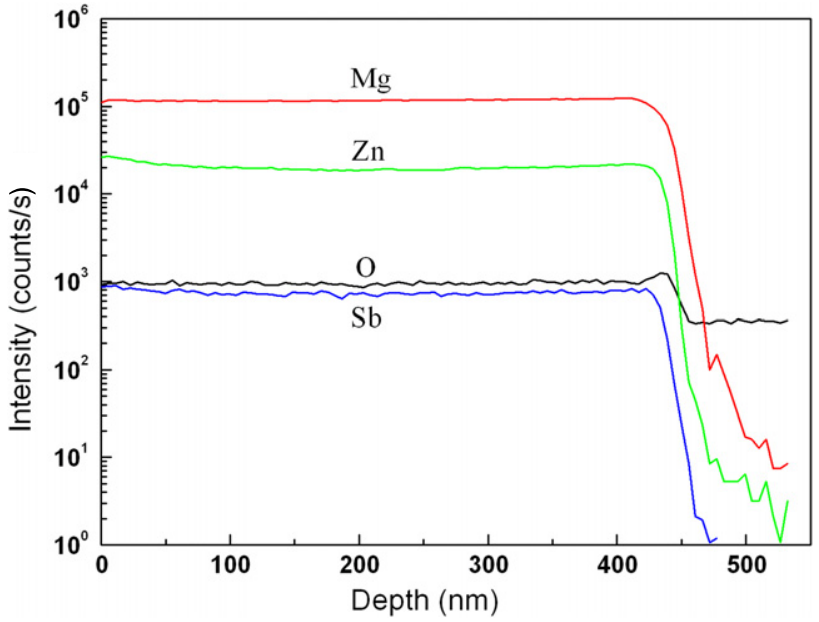

Figure 2. SIMS depth profile of the Sb-doped $\mathrm{Zn}_{0.95} \mathrm{Mg}_{0.05} \mathrm{O}$ thin film.

energy and potentially away from the intrinsic shallow donor state, thus increasing the activation energy of the defect donors and reducing the background electron concentration [12]. Therefore, it is possible that the better electrical properties of the $\mathrm{Sb}$-doped $\mathrm{Zn}_{0.95} \mathrm{Mg}_{0.05} \mathrm{O}$ thin film are attributed to the incorporation of $\mathrm{Mg}$, which will reduce the background electron concentration. To investigate the stability of the p-type conductivity, Hall-effect measurements were performed again 30 days later. It is found that the Sb-doped p-type $\mathrm{Zn}_{0.95} \mathrm{Mg}_{0.05} \mathrm{O}$ thin films still keep the p-type conductivity without any obvious degradation.

In order to investigate the element composition distribution in the Sb-doped $\mathrm{Zn}_{0.95} \mathrm{Mg}_{0.05} \mathrm{O}$ thin film, a depth profile was carried out by SIMS measurements, as shown in figure 2. Quantitative results could not be obtained due to the lack of reference samples for the SIMS measurement. The contents of $\mathrm{Zn}, \mathrm{Mg}$ and $\mathrm{O}$ keep constant throughout the whole film. Also, Sb has been well detected, uniformly distributed in the film, which is responsible for the p-type conductivity.

PL measurements were performed to characterize the optical properties of the $\mathrm{Sb}$-doped $\mathrm{ZnO}$ and the $\mathrm{Sb}$-doped $\mathrm{Zn}_{0.95} \mathrm{Mg}_{0.05} \mathrm{O}$ thin films. The room-temperature PL spectra are presented in figure 3. The Sb-doped $\mathrm{Zn}_{0.95} \mathrm{Mg}_{0.05} \mathrm{O}$ thin film as well as the Sb-doped $\mathrm{ZnO}$ thin film exhibits a peak located in the UV region, which originates from the excitonic near-band-gap emission. The emission of Sb-doped $\mathrm{Zn}_{0.95} \mathrm{Mg}_{0.05} \mathrm{O}$ is located at $3.48 \mathrm{eV}$, showing a blueshift compared with that of Sb-doped $\mathrm{ZnO}(3.23 \mathrm{eV})$. This blueshift is believed to be the result of the incorporation of $\mathrm{Mg}$. The comparative PL spectra suggest that $\mathrm{Mg}$ doping contributes to the bandgap widening in the Sb-doped $\mathrm{Zn}_{0.95} \mathrm{Mg}_{0.05} \mathrm{O}$ thin film. 


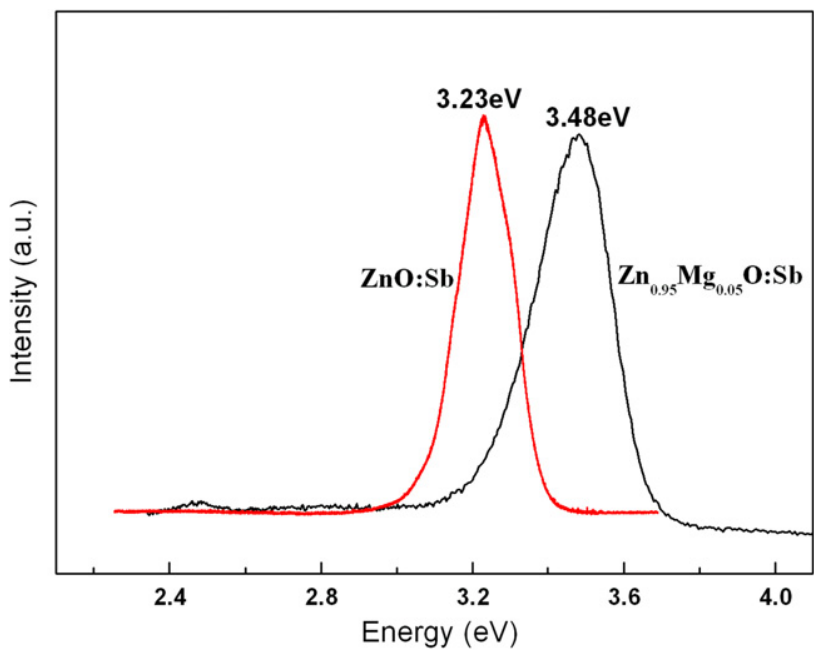

Figure 3. Room-temperature PL spectra of Sb-doped $\mathrm{ZnO}$ and $\mathrm{Sb}$-doped $\mathrm{Zn}_{0.95} \mathrm{Mg}_{0.05} \mathrm{O}$ thin films.

To further understand the doping behaviour of Sb, XPS spectra of the Sb-doped p-type $\mathrm{Zn}_{0.95} \mathrm{Mg}_{0.05} \mathrm{O}$ thin film were provided. Figure 4 shows the XPS spectra of $\mathrm{Mg} 1 \mathrm{~s}$ and $\mathrm{Sb} 3 \mathrm{~d}_{3 / 2}$ core levels of the $\mathrm{Sb}$-doped $\mathrm{Zn}_{0.95} \mathrm{Mg}_{0.05} \mathrm{O}$ thin film. The concentrations of $\mathrm{Sb}$ and $\mathrm{Mg}$ in the film were calculated to be 2.5 at $\%$ and 5.4 at $\%$, respectively, agreeing well with that in the targets. Figure $4(a)$ shows the $\mathrm{Mg} 1 \mathrm{~s}$ narrow scan spectrum for the Sb-doped $\mathrm{Zn}_{0.95} \mathrm{Mg}_{0.05} \mathrm{O}$ thin film. The peak at $1303.7 \mathrm{eV}$ is attributed to $\mathrm{Mg}-\mathrm{O}$ bonding, which confirms that the $\mathrm{Mg}$ atoms in the deposited films are bonded to the $\mathrm{O}$ atoms. Figure $4(b)$ illustrates the $\mathrm{Sb}$ $3 \mathrm{~d}_{3 / 2}$ narrow scan spectrum. The peak of the $\mathrm{Sb} 3 \mathrm{~d}_{3 / 2}$ core level can be fitted into one Gaussian peak on deducting the base line, which indicates that only one chemical bonding state of $\mathrm{Sb}$ is existing in the $\mathrm{Sb}$-doped $\mathrm{Zn}_{0.95} \mathrm{Mg}_{0.05} \mathrm{O}$ thin film. Isolated $\mathrm{Sb}$ may form $\mathrm{Sb}_{\mathrm{Zn}}$ (Sb occupying $\mathrm{Zn}$ site), $\mathrm{Sb}_{\mathrm{O}}$ (Sb occupying $\mathrm{O}$ site), or interstitial $\mathrm{Sb}_{\mathrm{i}}$. The $\mathrm{Sb} 3 \mathrm{~d}_{3 / 2}$ peak centred at $540 \mathrm{eV}$ is generally attributed to $\mathrm{Sb}-\mathrm{O}$ bonding. Therefore, it is concluded that $\mathrm{Sb}$ incorporated in the film should exist as $\mathrm{Sb}_{\mathrm{Zn}}$ rather than as $\mathrm{Sb}_{\mathrm{O}}$. However, isolated $\mathrm{Sb}_{\mathrm{Zn}}$ acts as a donor rather than an acceptor, which will not result in p-type conductivity. Thus, it is reasonable to infer that another Sb-related acceptor state is existing in the Sb-doped $\mathrm{Zn}_{0.95} \mathrm{Mg}_{0.05} \mathrm{O}$ thin film. Recently, a model for large-sizemismatched group- $\mathrm{V}$ dopants in $\mathrm{ZnO}$ has been proposed [13], in which an $\mathrm{Sb}_{\mathrm{Zn}}-2 \mathrm{~V}_{\mathrm{Zn}}$ complex (Sb occupying $\mathrm{Zn}$ site and spontaneously inducing two $\mathrm{Zn}$ vacancies) has been reported to be the most likely defect to form a shallow acceptor level with low formation energy of $2.00 \mathrm{eV}$ in Sb-doped $\mathrm{ZnO}$. In addition, the direct observation of As on the $\mathrm{Zn}$ site has been reported in As-doped $\mathrm{ZnO}$ and a similar $\mathrm{As}_{\mathrm{Zn}}-2 \mathrm{~V}_{\mathrm{Zn}}$ complex has been proposed [14]. With these considerations, the clear $\mathrm{p}$ type behaviour in the $\mathrm{Sb}$-doped $\mathrm{Zn}_{0.95} \mathrm{Mg}_{0.05} \mathrm{O}$ thin film is most likely attributed to the $\mathrm{Sb}_{\mathrm{Zn}}-2 \mathrm{~V}_{\mathrm{Zn}}$ complex in the present case.

\section{Conclusions}

In summary, Sb-doped p-type $\mathrm{Zn}_{0.95} \mathrm{Mg}_{0.05} \mathrm{O}$ thin films have been prepared by the PLD method. The incorporation of an $\mathrm{Sb}$ acceptor is confirmed by SIMS as well as by XPS.
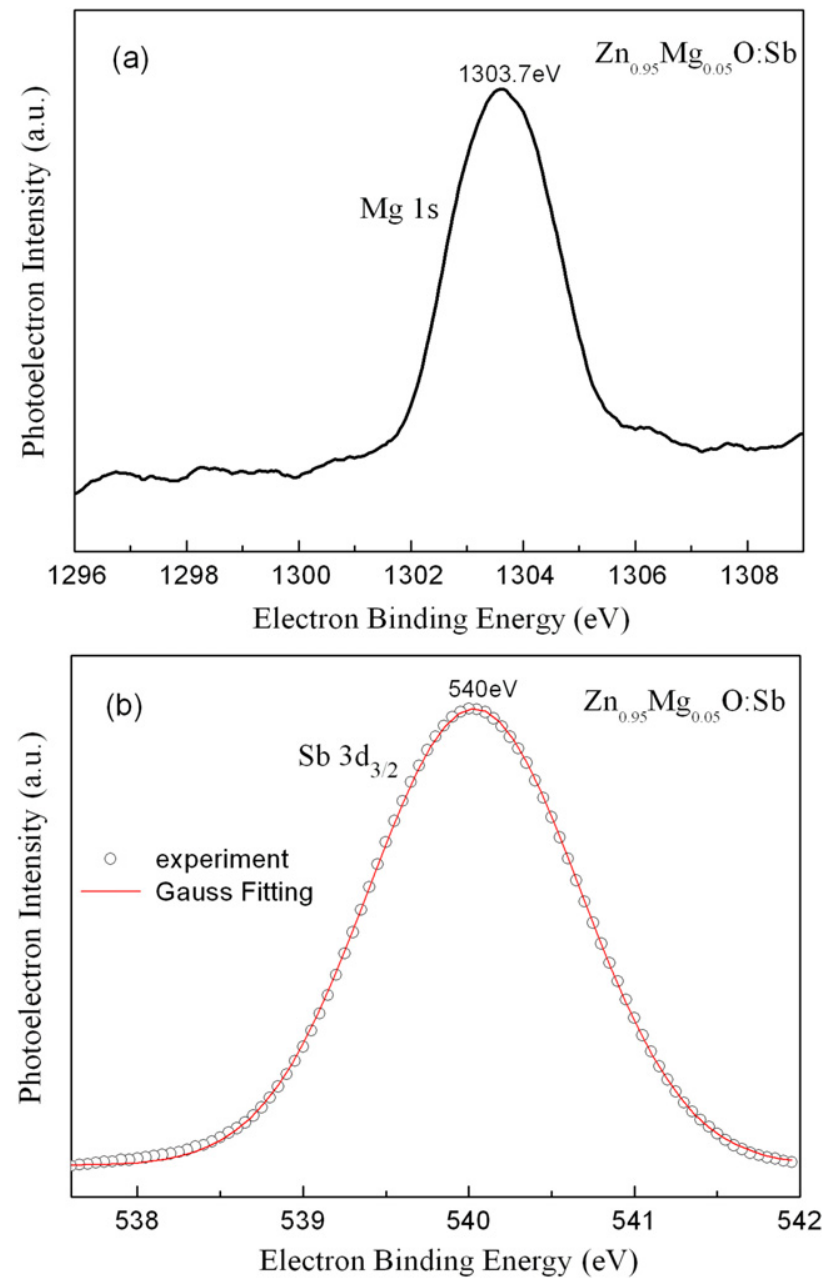

Figure 4. XPS spectra of the Sb-doped $\mathrm{Zn}_{0.95} \mathrm{Mg}_{0.05} \mathrm{O}$ thin film grown at $400{ }^{\circ} \mathrm{C}:(a) \mathrm{Mg} 1 \mathrm{~s},(b) \mathrm{Sb} 3 \mathrm{~d}_{3 / 2}$.

A blueshift in PL emission due to the introduction of $\mathrm{Mg}$ is observed in the $\mathrm{Zn}_{0.95} \mathrm{Mg}_{0.05} \mathrm{O}$ thin film. The $\mathrm{Sb}_{\mathrm{Zn}}-2 \mathrm{~V}_{\mathrm{Zn}}$ complex is considered to be the most probable candidate to form a shallow acceptor level in the Sb-doped $\mathrm{Zn}_{0.95} \mathrm{Mg}_{0.05} \mathrm{O}$ thin film. More detailed investigations on the Sb-doped $\mathrm{ZnMgO}$ thin films are in progress. These results will represent meaningful steps for $\mathrm{ZnO} / \mathrm{ZnMgO}$ superlattices, quantum wells and UV optoelectronic devices.

\section{Acknowledgments}

This work was supported by the National Basic Research Program of China under Grant No 2006CB604906, National Natural Science Foundation of China under Grant No 50532060 and Zhejiang Provincial Natural Science Foundation of China under Grant No Y405126.

\section{References}

[1] Tang Z K, Wong G K L, Yu P, Kawasaki M, Ohtomo A Koinuma H and Segawa Y 1998 Appl. Phys. Lett. 723270

[2] Look D C 2001 Mater. Sci. Eng. B 80383

[3] Sun H D, Makino T, Segawa Y, Kawasaki M, Ohtomo A, Tamura K and Koinuma H 2002 J. Appl. Phys. 911993 
[4] Zhang S B, Wei S H and Zunger A 2001 Phys. Rev. B 63075205

[5] Tsukazaki A et al 2005 Nature Mater. 442

[6] Ryu Y, Lee T S, Lubguban J A, White H W, Kim B J, Park Y S and Youn C J 2006 Appl. Phys. Lett. 88241108

[7] Xu W Z, Ye Z Z, Zeng Y J, Zhu L P, Zhao B H, Jiang L, Lu J G, He H P and Zhang S B 2006 Appl. Phys. Lett. 88173506

[8] Nause J, Pan M, Rengarajan V, Nemeth W, Ganesan S, Payne A, Li N and Ferguson I 2005 Proc. SPIE 5941 59410D
[9] Li Y J, Heo Y W, Kwon Y, Ip K, Pearton S J and Norton D P 2005 Appl. Phys. Lett. 87072101

[10] Zhang X, Li X M, Chen T L, Zhang C Y and Yu W D 2005 Appl. Phys. Lett. 87092101

[11] Wang P, Chen N F, Yin Z G, Dai R X and Bai Y M 2006 Appl. Phys. Lett. 89202102

[12] Heo Y W, Kwon Y W, Li Y, Pearton S J and Norton D P 2004 Appl. Phys. Lett. 843474

[13] Limpijumnong S, Zhang S B, Wei S H and Park C H 2004 Phys. Rev. Lett. 92155504

[14] Wahl U, Rita E, Correia J G, Marques A C, Alves E and Soares J C 2005 Phys. Rev. Lett. 95215503 